\title{
Metaphorical modelling in the case of cosmetic companies' image development
}

\author{
Oryslava Ivantsiv* \\ Ternopil Volodymyr Hnatiuk National Pedagogical University, Ukraine
}

\begin{abstract}
The article focuses on metaphorical modelling as a means of corporate image development. The research data includes an electronic corpus of 185 press releases issued by five international cosmetic companies. A methodology of analysing metaphorical models based on the consideration of the model's frame-slot structure was applied. The study resulted in the singling out of two major metaphorical clusters within the corporate discourse of image-making - BUSINESS IS A HUMAN BEING and BUSINESS IS ART. Although these models do not embrace the whole range of sources of metaphorical expansion, they nevertheless essentially contribute to creating a relatively holistic image of a cosmetic company as a perfect organism that produces masterpieces to meet the needs and expectations of the target audience.
\end{abstract}

\section{Key words}

metaphorical model, conceptual metaphor, frame-slot structure, corporate image, corporate discourse of image-making

\section{Introduction}

One of the most effective means of image formation is conceptual metaphor, the study of which in various discourse types has recently become a promising area of cognitive linguistics. Metaphorical modelling as a mechanism of perception, categorization and structuring of a certain fragment of reality holds an important place in the development of corporate images. Communication in corporate imagemaking as a field of professional activity related to the construction of the positive image of a company is realized through the corporate discourse of image-making. Corporate image-making has undoubtedly become one of the most versatile and rapidly developing discursive activities of business corporations due to the increasing importance of communication. In order to enhance competitiveness, to seize and retain a position in the market, to achieve a good reputation and to increase profits, corporations need to create a positive corporate image and to establish optimal communicative processes.

Within the cognitive and discursive paradigms of today's linguistics, the methodology of metaphorical modelling is noticeably growing in importance. It is particularly significant for corporate image-making since the process of a company's image construction is cognitive in its nature, reflecting the mental processes of information perception, selection, systematization and structuring. Image as a peculiar mental formation, a conception of an object, emerges in the human mind, and,

\footnotetext{
*Address for correspondence: Oryslava Ivantsiv, Faculty of Foreign Languages, Ternopil Volodymyr Hnatiuk National Pedagogical University, 2 M. Kryvonosa Street, Ternopil, Ukraine. E-mail: orysya_ivantsiv@yahoo.com
} 
consequently, it is reasonable to use the theoretical framework and methods of cognitive linguistics to analyse the dual, cognitive and verbal, nature of this phenomenon.

Conceptual metaphors in business discourse have already attracted the attention of linguists (see, for example, Grygiel, 2016; Kovacs, 2007; López Maestre, 2000). However, metaphorical modelling as a cognitive technique of a company's image creation has not so far become an object of comprehensive study. The present paper, therefore, aims to analyse the two major metaphorical models in the international cosmetic companies' corporate discourse of image-making and to reveal their prominent features.

\section{Theoretical framework}

The theory of metaphorical modelling was developed on the basis of the theories of conceptual metaphor (Lakoff and Johnson, 1980) and of regular polysemy elaborated by Russian linguists as part of the structural and semantic description of language (Chudinov, 1990; Sternin,1985).

At the present stage of linguistics development, there has been observed a shift from the traditional view of metaphor as a trope, serving as a means of enhancing language expressivity, to treating this phenomenon as a mental operation and a way of perceiving the world. The cognitive foundations of metaphorization have been described in a number of linguistic studies (Gibbs, 1994; Kittay, 1987; Kövecses, 2010; Lakoff and Johnson, 1980; McCormack, 1985; Fauconnier and Turner, 2003).

In cognitive linguistics, the theory of conceptual metaphor formulated by the US scholars Lakoff and Johnson in their work Metaphors We Live By has become noticeably widespread. Within this theory, conceptual metaphor is defined as the process of understanding one idea in terms of another (Lakoff and Johnson, 1980). The mechanism of metaphorical conceptualization consists in linking the knowledge structures of two different conceptual domains - the source domain, which is more specific and known, and the target domain, which is more obscure and abstract (Lakoff and Johnson, 1980). The systematic set of correspondences that exist between constituent elements of these domains is called mapping or projection. Thus, the procedure of metaphorical conceptualization consists of the mapping of the source domain onto the target domain.

The theory of conceptual metaphor branched off into the neural theory of metaphor. Its fundamental tenet is the vision of conceptual metaphor as a mapping between frames rather than domains. The technique of mapping has a neurophysiological nature and is based on interrelated activation of neural zones (Lakoff, 2008). The frame is understood as a network of slots united by meaningful connections that constitute permanent structures of knowledge representation (Evans and Green, 2008).

According to the theory of conceptual metaphor, human knowledge about the world is structured in the form of mental models (Johnson-Laird, 1983). A mental model is a structure of knowledge representation which corresponds to the structure of a certain situation and combines the information of all sensory systems and the general knowledge about everything that exists in the world. Mental models are based on the perception of reality depending on reality itself, human knowledge and experience.

One of the basic mental models involved in the creation of a new way of presenting and interpreting an object is the metaphorical model. The existence of metaphorical models in the human psyche provides the foundation for the use of metaphors in language. A conceptual metaphor manifests itself in text or discourse (Kövecses, 2010) in the form of an integral system of metaphorical models. This approach was developed into the theory of conceptual blending (Fauconnier and Turner, 2003), which reveals the mechanism of forming new meanings within a new metaphorical structure in the text (Lakoff, 2008). Such models have enormous potential in language implementation ranging from traditional lexical and semantic variation to text or discourse formation (Mishankina, 2009). Hence, it is important to use a discursive approach to the description of metaphorical models, which accounts for the communicative circumstances of their origin and functioning.

The term "metaphorical model" is applied to a group of conceptual metaphors united by one source domain. Following Chudinov (2003, p.131), we treat the metaphorical model as "a pattern of connection between the conceptual domains which exists or forms in the native speaker's mind and can be represented by a formula: $\mathrm{X}$ is $\mathrm{Y}$ ". According to this formula, the system of frames of one mental sphere serves as a basis for modelling another mental sphere. 


\section{Corpus and methods}

The corpus of the data used for this study consists of 185 press releases issued by five international cosmetic companies, namely Avon Products, Inc., Elizabeth Arden, Inc., Estee Lauder Companies, Inc., Mary Kay, Inc. and Revlon, Inc. between 2010 and 2017 and accessed on the company's websites. These companies are among the world's leading manufacturers and marketers of skin care, makeup, fragrance and hair care products.

The reason for selecting electronic press releases as research material is due to their recognized role in displaying relevant information about a company aimed at accumulating publicity capital and developing a positive corporate image. The online press release, as one of the main genres of the corporate discourse of image-making, is widely represented on the websites of cosmetic companies, occupying the majority of the allocated discourse space. This fact obviously accounts for its significant role in shaping public opinion regarding the company and its activities.

The collected data were analysed both in qualitative and quantitative terms within the theoretical framework of cognitive linguistics. The research started with the identification of metaphorical expressions in the texts. The total number of selected metaphorical expressions was more than 2,500. They were classified in accordance with their representative source domains into metaphorical models. The study resulted in the singling out of two major metaphorical clusters of the corporate discourse of image-making, which comprise 1,640 metaphorical expressions. The revealed metaphorical expressions were also statistically measured in terms of their frequency across conceptual domains.

The analysis of metaphorical models was conducted on the basis of a methodology designed by Chudinov (2001), which consists of the description of their frame-slot structure. The procedure included the following stages:

- description of the source domain of metaphorical expansion to which non-metaphorical meanings of metaphorical expressions belong;

- description of the target domain of metaphorical borrowing to which metaphorical meanings of the expressions belong;

- analysis of the cognitive frames which refer to a certain metaphorical model. We assume that conceptual domains are structured as the frames which reflect acquired information about a stereotypical situation and the text which describes it. The system of frames often appears to be a peculiar cognitive dynamic scenario which mirrors the sequences of situations typical of the source domain;

- analysis of the slots typical of a certain cognitive frame. They are the elements of the situation which include a certain part of the frame, that is, a certain aspect of its concretization. Concepts as units of mental lexicon most frequently activated by words associated with them are used for the analysis of slot components;

- identification of the component which connects the primary and secondary meanings of metaphorical expressions embraced by a certain metaphorical model;

- description of the discursive characteristics of a metaphorical model, including the conceptual vectors, prominent emotive features and pragmatic potential of a model, its connection with the communicative situation and the intentions of its participants;

- assessment of the productivity of a metaphorical model and the frequency of its use with due regard for genre, stylistic, pragmatic and other features of the text.

With the help of the outlined analytical procedure we are closer to detecting the prominent features of metaphorical modelling of a cosmetic company's corporate image.

\section{Results and discussion}

\subsection{Metaphorical modelling of a cosmetic company's image}

A distinctive cognitive feature of the corporate discourse of image-making is its metaphorical nature. To elucidate the complex concepts belonging to the conceptual sphere of this discourse, phenomena that are acceptable to the target audience and simple to interpret are required. The press releases of international cosmetic companies are rich in conceptual metaphors which appear to be a powerful means of influencing public consciousness. 
Conceptual metaphor in the corporate discourse of image-making can be defined as a tool to shape the positive attitude of the target audience towards the company and the results of its activities and thus to create an attractive image of the organization. Business realities are fixed in the minds of the audience as concepts based on categories from other fields.

The specific character of metaphorical modelling in the sphere of corporate image development lies in the fact that the basis for metaphor identification and classification is the target domain of business that draws concepts from different thematic fields, which prove to be sources of metaphorical expansion in the corporate discourse of image-making.

The analysis results in the singling out of two dominant metaphorical clusters within the discourse - BUSINESS IS A HUMAN BEING and BUSINESS IS ART which do not embrace the whole range of sources of metaphorical expansion but, nevertheless, create a relatively holistic impression of the corporate image. The study has shown that BUSINESS IS A HUMAN BEING is the most frequently used metaphorical model which constitutes 952 metaphorical expressions (58\%) while BUSINESS IS ART occupies second place in the press releases of international cosmetic companies and amounts to 688 metaphorical expressions (42\%).

\subsection{Metaphorical model BUSINESS IS A HUMAN BEING}

One of the two basic metaphorical models in the corporate discourse of image-making is BUSINESS IS A HUMAN BEING. It seems to be a leading mechanism in coding information about the organization's activities. Cosmetic companies are conceptualized by means of metaphorical expressions denoting the mental faculties of a human being, the human body with its physiological processes, and social and family life. Anthropomorphic metaphors are created based on various similarities between business realities and parts of the human body, family relationships, and the biological and social characteristics of a person. Table 1 shows the relatively complex frame-slot structure of this metaphorical model.

Table 1. The frame-slot structure of the metaphorical model BUSINESS IS A HUMAN BEING and the frequency of its use in the texts of press releases

\begin{tabular}{|c|c|c|c|}
\hline Frames & $\%$ & Slots & $\%$ \\
\hline \multirow{3}{*}{$\begin{array}{l}\text { Frame 1. Parts of the } \\
\text { Human Body }\end{array}$} & \multirow{3}{*}{15} & Slot 1.1. Head & 5 \\
\hline & & Slot 1.2. Heart & 6 \\
\hline & & Slot 1.3. Face & 4 \\
\hline \multirow{3}{*}{$\begin{array}{l}\text { Frame 2. Physiological } \\
\text { Processes }\end{array}$} & \multirow{3}{*}{13} & Slot 2.1. Birth & 4 \\
\hline & & Slot 2.2. Growth & 4 \\
\hline & & Slot 2.3. Breathing & 5 \\
\hline \multirow{2}{*}{$\begin{array}{l}\text { Frame 3. Character and } \\
\text { Emotional State }\end{array}$} & \multirow[b]{2}{*}{11} & Slot 3.1. Character Traits & 6 \\
\hline & & Slot 3.2. Emotional State & 5 \\
\hline $\begin{array}{l}\text { Frame 4. Human } \\
\text { Actions }\end{array}$ & 9 & & 9 \\
\hline \multirow{3}{*}{$\begin{array}{l}\text { Frame 5. Family } \\
\text { Relationships }\end{array}$} & \multirow{3}{*}{10} & Slot 5.1. Marriage & 2 \\
\hline & & Slot 5.2. Family & 4 \\
\hline & & Slot 5.3. Family Members & 4 \\
\hline
\end{tabular}

Frame 1. PARTS OF THE HUMAN BODY

Metaphorical expressions denoting body parts create the image of a cosmetic company as a wellformed human organism. Since each part is vital for the functioning of a human body, their presence in press releases emphasizes the importance of business elements in the cosmetic industry. This frame includes the following slots. 
Slot 1.1. HEAD. The head not only houses and protects the brain and other organs but also performs the function of general control over the human organism. Not surprisingly, the concept head is used for the metaphorical representation of business leaders, e.g.:

(1) Winners will be selected by an expert panel comprised of notable figures, philanthropic leaders and heads of business (Avon Products, Inc.).

Slot 1.2. HEART. The heart is the central organ of the human organism. The concept of heart serves as a spatial orientation point which is metaphorically used in the meaning of the centre, nucleus, core, as in the following example:

(2) Since the early days, Avon Representatives have made the personal relationship the heart of their businesses (Avon Products, Inc.).

Slot 1.3. FACE. The authors of press releases of international cosmetic companies use the concept of face to designate the essence of the company's activities and to provide the basis for the target audience's perception and the formation of the positive corporate image, for instance:

(3) Her revolutionary marketing ideas changed the face of the beauty industry and continue to serve as our greatest inspiration (Estee Lauder Companies, Inc.);

(4) Avon, Inc. today announced a partnership with award-winning international actress, Jacqueline Bisset, who will serve as the face of the revolutionary ANEW Platinum line (Avon Products, Inc.).

Frame 2. PHYSIOLOGICAL PROCESSES

Some business phenomena and processes in the cosmetic industry may metaphorically be represented as vital functions of the human organism. This frame embraces the following slots.

Slot 2.1. BIRTH. The start of any new cosmetic company in the international market, the appearance of new philanthropic initiatives and lines of cosmetic and perfumery products are seen as the birth of a child, for example:

(5) "I've always loved Origins, and coming to the brand, I've really learned so much about its history. It was born in the 1980s during an explosion of excess <...>," said Jane Lauder (Estee Lauder Companies, Inc.).

Slot 2.2. GROWTH. International cosmetic companies are characterized by active expansion in their market segment, signalled by the use of the lexemes grow and growth in corporate press releases, e.g.:

(6) From its meager start in a 500-square-foot storefront in Dallas, Texas, Mary Kay Inc. has grown into an international cosmetics powerhouse (Mary Kay, Inc.);

(7) Since 1990, Mary Kay has experienced significant growth, opening in more than 20 new markets around the world (Mary Kay, Inc.).

Slot 2.3. BREATHING. Since breathing is of vital importance for the preservation of life, the cosmetic products of international companies are metaphorically depicted by the words breath and breathable, e.g.:

(8) Freshwear Complex helps maintain the quality of just-applied foundation as the formula's stretchable, breathable network leaves skin feeling comfortable (Avon Products, Inc.);

(9) Stressed, irritated skin appears soothed, as the oxygenating benefits of a concentrated brown algae, Laminaria digitata, breathes life into the skin (Estee Lauder Companies, Inc.). 
Frame 3. CHARACTER AND EMOTIONAL STATE

Within the model of the human organism, cosmetic companies are seen as creatures with both physical and mental characteristics. Each of them has its own character, and, furthermore, they are capable of expressing feelings and entering different emotional states and moods. This frame is represented by the following slots.

Slot 3.1. CHARACTER TRAITS. Cosmetic companies exhibit various human features, which together contribute to the representation of a company as an animate object. This can be illustrated by the following examples:

(10) "I am proud to serve as Avon Global Ambassador and represent a company with a conscience and the courage to take on hard issues <...>, " says Witherspoon (Avon Products, Inc.);

(11) "As the company for women, Avon feels an obligation and responsibility to play a leadership role in helping to improve the lives of women around the world, and we truly believe we can make a difference," says Ms. Jung (Avon Products, Inc.).

Slot 3.2. EMOTIONAL STATE. The companies in the cosmetic industry demonstrate various emotional states in corporate press releases, e.g.:

(12) Janet Saunders, general manager for Clinique in the UK, says of the partnership: "Clinique is delighted to be teaming up with the GB Beach Volleyball hopefuls Denise and Lucy <...>" (Estee Lauder Companies, Inc.);

(13) "Revlon was thrilled to partner with rag \& bone and offer our consumers the chance of a lifetime - meet our gorgeous Global Brand Ambassador Halle Berry and get an exclusive makeover with the talented Gucci Westman. It was truly a magical night," says Martine Williamson, VP of Marketing for Revlon (Revlon, Inc.).

Frame 4. HUMAN ACTIONS

By using metaphorical expressions denoting human actions, the authors of international cosmetic companies' press releases metaphorically represent the main directions of business activities, as in the following example:

(14) This is the company that puts mascara on lashes and food on tables that fights wrinkles with one hand and Breast Cancer with the other. That knows the value of a perfect lip, but still opens its mouth and speaks out against Domestic Violence and for women's financial independence. This is the company that not only brings beauty to doors, but also opens them. The company that supports more than 6 million Representatives in over 100 countries. This is Avon. The company that for more than 125 years has stood for beauty, innovation, optimism and above all for women (Avon Products, Inc.).

This discourse fragment shows that the Avon company positions itself as a socially responsible organization which cares about the society in which it works.

Frame 5. FAMILY RELATIONSHIPS

The relations between business participants are conceptually represented as based on family ethics, as those between the closest people in the family. The frame includes the slots described below.

Slot 5.1. MARRIAGE. A tight union of current achievements in science and art for the sake of high-quality personal care products development is conceptualized as marriage, e.g.:

(15) The company needed to marry high tech with high touch. And it did (Avon Products, Inc.).

Slot 5.2. FAMILY. The cosmetic company is frequently metaphorically represented in corporate press releases as a family which consists of branches and brands, for instance: 
(16) Here, at The Estée Lauder Companies, you are family from day one (Estee Lauder Companies, Inc.);

(17) We are a family of distinctive brands and entrepreneurial business leaders (Estee Lauder Companies, Inc.);

(18) Our diverse and dynamic family of more than 25 world-class brands touches half a billion consumers a year (Estee Lauder Companies, Inc.).

The family metaphors in these fragments reflect the nature of relationships between different brands of Estee Lauder Companies, for example, between management and subordinates and also among workers themselves. These relations are characterized, as seen from the above fragments, by respect, understanding and harmony. Such a metaphorical representation allows image-makers to create a positive image of the corporation as an ideal workplace.

Slot 5.3. FAMILY MEMBERS. The founders and leaders of business structures are shown as careful parents who take care of their employees as if they were their own children, e.g.:

(19) "Sometimes," says Mary Kay Ash, "I'm like a mother who wants to give her children the things she didn't have" (Mary Kay, Inc.).

Overall, the analysis has shown that the metaphorical model BUSINESS IS A HUMAN BEING is well structured. It illustrates the versatility of human life - from primary physiological processes to complicated social relations. This metaphorical model reveals the communicative intention of the authors of press releases to characterize the sphere of the cosmetic industry on the scale of values comprehensible to the majority of the target consumers. The analysed model can be treated as representing the conceptual vector of completeness and perfection.

\subsection{Metaphorical model BUSINESS IS ART}

The second dominant metaphorical model is BUSINESS IS ART which has a considerable emotional potential realized in the metaphorical modelling of corporate image. There are numerous features which connect business and art. This especially concerns the cosmetic industry where every manufactured product is identified based on an implicit or explicit comparison with a work of art. Not surprisingly, in the press releases of international cosmetic companies business activities and products are conceptualized as phenomena and objects from the spheres of music, literature, and visual and performing arts. Table 2 shows the diversified frame-slot structure of the considered metaphorical model. 
Table 2. The frame-slot structure of the metaphorical model BUSINESS IS ART and the frequency of its use in the texts of press releases

\begin{tabular}{|c|c|c|c|}
\hline \multirow{4}{*}{$\begin{array}{l}\text { Frame } 1 . \text { Theatrical and } \\
\text { Cinematographic Art }\end{array}$} & $\%$ & Slots & $\%$ \\
\hline & \multirow{3}{*}{14} & $\begin{array}{l}\text { Slot 1.1. Genres of Theatrical } \\
\text { and Cinematographic Art }\end{array}$ & 4 \\
\hline & & $\begin{array}{l}\text { Slot 1.2. Dramatic Performance } \\
\text { Staging }\end{array}$ & 6 \\
\hline & & Slot 1.3. Setting & 4 \\
\hline \multirow[b]{2}{*}{ Frame 2. Musical Art } & \multirow[b]{2}{*}{12} & Slot 2.1. Musicians & 5 \\
\hline & & $\begin{array}{l}\text { Slot 2.2. Musical Piece and its } \\
\text { Elements }\end{array}$ & 7 \\
\hline \multirow{3}{*}{ Frame 3 . Fine Art } & \multirow{3}{*}{9} & Slot 3.1. Fine Art Works & 4 \\
\hline & & Slot 3.2. Types of Fine Art & 3 \\
\hline & & Slot 3.3. Art Tools & 2 \\
\hline $\begin{array}{l}\text { Frame } 4 \text {. Literary } \\
\text { Creativity }\end{array}$ & 7 & Slot 4.1. Poetry & 7 \\
\hline
\end{tabular}

Frame 1. THEATRICAL AND CINEMATOGRAPHIC ART

The press releases of international cosmetic companies demonstrate the transfer of notions from the domain of theatrical art and cinematography onto the cognitive plane of business activities. This frame includes the following slots.

Slot 1.1. GENRES OF THEATRICAL AND CINEMATOGRAPHIC ART. The analysis has shown that the authors of press releases of international cosmetic companies frequently use the lexeme drama and its derivatives, for instance:

(20) With the new Super Drama Mascara from Avon, all it takes is one sweep to get sultry, long lashes that are plumped to the max (Avon Products, Inc.).

The concept of drama in this fragment adds a powerful touch to the description of the Avon product and, thus, facilitates the construction of its positive corporate image.

Slot 1.2. DRAMATIC PERFORMANCE STAGING. The analysed texts often depict the cosmetic industry as a dramatic performance with all the roles distributed between the employees according to a certain scenario. The release of products is manifested as a debut or a premiere, for example:

(21) Once again, Avon revolutionizes anti-aging skincare with the debut of ANEW Platinum, a new line for women 60+ that recaptures the look of youthful contours (Avon Products, Inc.);

(22) Avon introduces Healthy Makeup, a premiere color collection committed to skin's health. More than just makeup, this collection is designed to address the three signs of healthy skin hydration, texture and radiance (Avon Products, Inc.).

Slot 1.3. SETTING. Business activities, similar to theatrical and cinematographic events, are either undertaken quite openly and transparently, as if on set, or secretly, as if from the backstage:

(23) " $<\ldots>$ These two ad executions capture unique aspects of our culture: great haircuts and styling as well as hairdressing authority backstage and on set in the fashion world," explains Peter Lichtenthal, President, Bumble and bumble (Estee Lauder Companies, Inc.).

The concept scene is used to present the cosmetic industry as having new brands that offer their unique products and special services and thus change the beauty market, e.g.: 
(24) It's impressive to think that Elizabeth Arden changed the Manhattan beauty scene in 1910 when she opened her own shop to sell fine quality cosmetics and skin care products at a time when few women wore makeup (Elizabeth Arden, Inc.).

Frame 2. MUSICAL ART

One of the effective means of positive corporate image development appears to be the use of the semantic capacity of lexemes from the realm of music. The analysed frame is represented by the slots outlined below.

Slot 2.1. MUSICIANS. Various types of beauty products are united in duo or trio in order to create polyphony in the cosmetic industry. The following fragment serves as an example:

(25) So whether you Love to the Fullest, Laugh Often, or Live Without Regrets, you can express yourself through the new fragrance trio (Avon Products, Inc.).

Slot 2.2. MUSICAL PIECE AND ITS ELEMENTS. The analysis reveals the frequent use of the musical terms note and accord which, in combination with the lexemes denoting nature-morphic objects, depict the ingredients of cosmetic masterpieces, e.g.:

(26) A mojito accord blending chilled lime, spearmint, rum notes and simple syrup infuses the fragrance with an addictive, intoxicatingly cool energy (Avon Products, Inc).

Moreover, the authors of the press releases of international cosmetic companies frequently use the concepts of rhythm and melody to metaphorically represent exclusive cosmetic products:

(27) A base of sensual musks wrapped in white amber and blonde cedar creates an enduring rhythm (Avon Products, Inc.);

(28) An expected sweetness gives this flower its bold signature and imparts a sophisticated, luscious melody to the scent (Avon Products, Inc.).

These metaphors evoke unforgettable images, stimulating the recipient's imagination. Overall, the metaphorical use of musical terms allows image-makers to create the image of a manufacturer of unique products, unbeatable in the international beauty market.

Frame 3. FINE ART

This frame is structured as follows.

Slot 3.1. FINE ART WORKS. Image-makers often metaphorically describe cosmetic products as pictures in order to create an illusion of being an ideal choice for those who long for stylistic perfection, for instance:

(29) Elizabeth Arden Pretty As A Picture Fragrance Set is a luxurious gift set that comes in a Keepsake Box (Elizabeth Arden, Inc.).

Cosmetic companies are portrayed as icons which can vividly be seen from the next fragment:

(30) Revlon, along with its Global Artistic Director Gucci Westman, will co-host the ultimate 'glam' party during New York's Fashion's Night Out on Thursday, September 6, 2012 to celebrate Revlon's 80-years as a beauty icon (Revlon, Inc.).

Slot 3.2. TYPES OF FINE ART. The founders of cosmetic companies are depicted as architects who manage to shape corporate culture, for example:

(31) She was one of the pivotal architects of our vision, values, and culture (Estee Lauder Companies, Inc.). 
Slot 3.3. ART TOOLS. The lexeme palette is frequently used in combination with the words denoting the production results of the company, as in the following fragment:

(32) Thousands of shades of pink have comprised Avon's palettes for blush, lipstick and eye shadow over the years (Avon Products, Inc.).

As clearly seen from the above, the Avon cosmetic company is viewed as an artist that uses a rich palette of beauty products to make its customers look exquisite.

\section{Frame 4. LITERARY CREATIVITY}

The metaphorical model BUSINESS IS ART is also developed by the systematic use of the notions and words from the domain of literary creativity. This frame is represented by the following slot.

Slot 4.1. POETRY. The authors of the press releases of international cosmetic companies metaphorically describe beauty products as poetic works, which can be seen from the following examples:

(33) An ode to the art of living well, Live Without Regrets is a Floral Fruity blend of lush petals and juicy fruit notes (Avon Products, Inc.);

(34) Your skin is embraced in the poetic blend of soft woods and vanilla (Avon Products, Inc.).

The metaphorical model BUSINESS IS ART allows customers to perceive the realities in the cosmetic market as art projects (dramatic performances, musical and literary compositions, or fine art works). This model generates images which realize the conceptual vectors of creativity.

\section{Conclusion}

This study suggests that metaphorical modelling is one of the most efficient means of corporate image construction and the main vehicle for the realization of image-makers' intentions. The frequent use of conceptual metaphors in the corporate discourse of image-making in the sphere of the international cosmetic industry testifies to the effectiveness of their use for corporate image development.

The research has shown that the most frequently used metaphorical models in the cosmetic industry's corporate discourse of image-making are BUSINESS IS A HUMAN ORGANISM and BUSINESS IS ART, which represent the conceptual vectors of completeness, perfection and creativity. The analysis of the frame-slot structure of these metaphorical clusters has revealed that they characterize business activities and products of international cosmetic companies from different perspectives. The choice of metaphorical models obviously influences the vision of this or that phenomenon in the commercial sector, reflecting different dimensions in the multidimensional space of business activities.

In the texts of corporate press releases, these metaphorical models contribute to the development of a powerful and vivid image of the cosmetic company, which is portrayed as a perfect organism of a multifaceted nature, able to create masterpieces to meet the needs and expectations of the audience. The interaction of the models intensifies and harmonizes the influence on the consciousness and subconsciousness of target consumers. This influence is internationally exerted to form a holistic impression of a cosmetic company as a reliable partner, a manufacturer of high quality products, a desirable employer and a benefactor.

It is anticipated that this research will serve as a methodological basis for future studies on metaphorical models that are less frequently used in the cosmetic industry's discourse of imagemaking as well as on appropriate models in other corporate discourses. However, it should be noted that the existence and use of metaphorical models can be constrained by language conventions and the genre of the texts. Further research, therefore, is needed to verify this assumption and to provide more relevant data and knowledge on metaphorical models in various corporate genres and in different languages. 


\section{References}

Chudinov, A., 2003. The metaphorical mosaic of modern political communication. Yekaterinburg, Ural State Pedagogical University (in Russian).

Chudinov, A., 1990. Regular semantic variation in the Russian verb lexicon. ScD thesis, Sverdlovsk (in Russian).

Evans, V. and Green, M., 2006. Cognitive linguistics: An introduction. Edinburgh: Edinburgh University Press.

Fauconnier, G. and Turner, M., 2003. The way we think: Conceptual blending and the mind's hidden complexities. New York: Basic Books.

Gibbs, R., 1994. The poetics of mind: Figurative thought, language and understanding. Cambridge: Cambridge University Press.

Grygiel, M., 2016. Conceptual metaphors structuring the process of 'business communication'. In: P. Bak and B. Rolek, eds. Wort zum Gebrauch. Wortbedeutung und ihre Eingebundenheit in Diskurse. Frankfurt am Main: Peter Lang, pp. 279-294.

Johnson-Laird, P., 1983. Mental models. Cambridge: MA, Harvard University Press.

Kittay, E. F., 1987. Metaphor: Its cognitive force and linguistic structure. Oxford: Clarendon Press.

Kovacs, E., 2007. Metaphors in English, German and Hungarian business discourse: A contrastive analysis. Eger Journal of English Studies, vol. 7, pp. 111-128.

Kövecses, Z., 2010. Metaphor: A practical introduction. Oxford: Oxford University Press.

Lakoff, G. and Johnson M., 1980. Metaphors we live by. Chicago: University of Chicago Press.

Lakoff, G., 2008. The neural theory of metaphor. In: R. W. Gibbs, ed. The Cambridge handbook of metaphor and thought. Cambridge: Cambridge University Press, pp. 17-39.

López Maestre, M. D., 2000. The business of cognitive stylistics: A survey of conceptual metaphors in business English. Atlantis, vol. 22, no. 1, pp. 47-69.

Mac Cormac, E., 1985. A cognitive theory of metaphor. Cambridge: MIT Press.

Mishankina, N., 2009. Metaphorical models of linguistic discourse. Vestnik TGU, no. 324, pp. 41-49 (in Russian).

Sternin, I., 1985. The lexical meaning of a word in speech. Voronezh: Voronezh University Press (in Russian).

\section{Internet sources:}

Avon Products Media Centre [Accessed 17 December 2017].

Available at: (http://media.avoncompany.com/index.php)

Elizabeth Arden [Accessed 15 December 2017].

Available at: (http://www.elizabetharden.com)

Estée Lauder Companies Newsroom [Accessed 17 December 2017].

Available at: (http://www.elcompanies.com/news-and-media/newsroom)

Mary Kay Press Room [Accessed 17 December 2017].

Available at: (https://newsroom.marykay.com/en/releases)

Revlon [Accessed 12 December 2017].

Available at: (http://www.revlon.com) 